ВЕСТНИК ПНИПУ. ГЕОЛОГИЯ. НЕФТЕГАЗОВОЕ И ГОРНОЕ ДЕЛО

PERM JOURNAL OF PETROLEUM AND MINING ENGINEERING

ISSN 2224-9923

Tom/Volume 18 №2, 2018

http://vestnik,pstu.ru/geo/

УДК 622.276:622.24.084.34

Article / Статья

(C) PNRPU / ПНИПУ, 2018

\title{
IMPROVEMENT OF THE CRITERIA FOR ASSESSING THE QUALITY OF HYDROCARBON-BASED MUDS IN TERMS OF GEOLOGICAL CONDITIONS OF THEIR USE
}

\section{Irina L. Nekrasova}

PermNIPIneft branch of LUKOIL-Engineering LLC in Perm (29 Sovetskoy Armii st., Perm, 614066, Russian Federation)

\section{СОВЕРШЕНСТВОВАНИЕ КРИТЕРИЕВ ОЦЕНКИ КАЧЕСТВА БУРОВЫХ РАСТВОРОВ НА УГЛЕВОДОРОДНОЙ ОСНОВЕ В ЗАВИСИМОСТИ ОТ ГОРНО-ГЕОЛОГИЧЕСКИХ УСЛОВИЙ ИХ ПРИМЕНЕНИЯ}

\section{И.Л. Некрасова}

Филиал ООО «ЛУКОЙЛ-Инжиниринг» «ПермНИПИнефть» в городе Перми (614066, Россия, г. Пермь, ул. Советской Армии, 29)

Received / Получена: 05.07.2018. Accepted / Принята: 24.10.2018. Published / Опубликована: 30.11.2018

Key words:

hydrocarbon-based muds, high deviation wells, mud quality criteria, softening coefficient, temperature dilution factor, flash point.

Ключевые слова: буровые растворы на углеводородной основе, скважины с большим отходом от вертикали, критерии качества буровых растворов, коэффициент разупрочнения, коэффициент температурного разжижения, температура вспышки.

\begin{abstract}
Nowdays, the area of possible application of hydrocarbon-based muds (HCBM) is significantly expanding in the foreign and domestic practice of well construction. There is a lot of examples of successful use of HCBM when drilling complex wells in various geological conditions. There is a negative experience that indicates that the selected composition and technological properties of the HCBM did not fully meet geological conditions of drilling. In particular, there are cases when wellbore was not stable, as well as the failure to achieve the planned production rate due to the low quality of reservoir drilling. In order to increase the effectiveness of HCBM use, it is important to develop criteria for assessing their quality depending on geological conditions of use, which allow for the operational control of the quality of a mud in field conditions. Based on many years of experience of HCBM application, an algorithm is proposed for selecting the quality criteria for this type of solution, depending on the geological conditions of use. Requirements for a HCBM during the drilling of high deviation wells, including intervals of unstable terrigenous deposits under high formation temperatures are considered. Criteria for assessing the quality of the initial opening of productive layers are proposed.

Criteria presented in the paper for assessing the quality of the HCBM will be useful for specialists in the field of drilling and production who are involved in the design and development of drilling fluids, including shale oil and gas deposits.
\end{abstract}

В настоящее время в зарубежной и отечественной практике строительства скважин область возможного применения буровых растворов на углеводородной основе (РУО) значительно расширяется. Известно достаточно много примеров успешного применения РУО при бурении скважин сложного профиля в различных геологотехнических условиях. Существует также и отрицательный опыт, свидетельствующий о том, что выбранный состав и технологические свойства РУО не в полной мере отвечали горно-геологическим условиям бурения. В частности, известны случаи потери устойчивости ствола скважины, а также недостижения планового дебита вследствие низкого качества первичного вскрытия продуктивного пласта. С целью повышения эффективности применения РУО актуальной является разработка критериев оценки их качества в зависимости от горно-геологических условий применения, позволяющих проводить оперативный контроль качества бурового раствора в промысловых условиях. На основании многолетнего опыта применения РУО предложен алгоритм выбора критериев качества данного типа растворов в зависимости от горно-геологических условий применения. Рассмотрены требования, предъявляемые к РУО при бурении скважин с большим отходом от вертикали, в том числе в интервалах неустойчивых терригенных отложений, в условиях повышенных пластовых температур. Предложены критерии оценки качества первичного вскрытия продуктивных пластов.

Представленные в статье критерии оценки качества РУО будут полезны специалистам в области бурения и добычи, занимающимся проектированием и разработкой буровых растворов, в том числе для сланцевых месторождений нефти и газа.

Irina L. Nekrasova (Author ID in Scopus: 56704818100) - PhD in Engineering, Senior Researcher at the Department of Muds and Process Fluids (tel.: +007 342 233 67 63, e-mail: Irina.Nekrasova@pnn.lukoil.com).

Некрасова Ирина Леонидовна - кандидат технических наук, ведущий научный сотрудник отдела буровых растворов и технологических жидкостей (тел.: +007342 23367 63, е-mail: Irina.Nekrasova@pnn.lukoil.com). 


\section{Introduction}

In the current foreign and domestic practice of wells construction, the potential scope of application of hydrocarbon-based drilling mud (HCBM) is significantly expanding. To a large extent this is the result of introduction of the technology for productive reservoir penetration with horizontal and horizontally branched wells that enables effective development of fields in the continental shelf, in natural reserves and hard-to-reach areas $[1,2]$. Based on a scientific data review, it was established that HCBM was used to drill most of the extended reach horizontal wells [3-5].

Based on the field experience of using HCBM in combination with advanced drilling technology $[6,7]$, it would be reasonable to split this type of drilling muds into the following groups based on their purpose:

1) for drilling of low-angle and horizontal extended reach wells;

2) for penetration of intervals with unstable terrigenous deposits;

3 ) for penetration of productive reservoirs with low porosity and permeability, in conditions where real well outputs with the use of water systems are much lower than potentially possible;

4) as process fluids for elimination of sticking and for improvement of hydrophobic properties of unstable intervals;

5) for core sampling in order to preserve its native properties;

6) as a fluid for secondary penetration and well killing.

Most of the presently used HCBM recipes are an emulsion of polar fluid in a nonpolar fluid, i.e. invert "water in oil" emulsion. "Oil" here means waterinsoluble oleophilic organic substances soluble in nonpolar mediums (traditional petroleum products, synthetic and agricultural oils) $[8,9]$. The basis for emergence of HCBM technological properties are the characteristics of the emulsion process between the two nearly mutually insoluble liquids: dispersion medium - the organic liquid and disperse phase water or water solutions of salt, in most cases calcium chloride.

\section{Algorithm for selection of HCBM quality criteria}

The technical research literature contains quite a lot of examples of successful HCBM application for drilling of directional wells in various geological and technical conditions [3, 10-13]. However, there are also negative instances where the selected HCBM composition and process properties were not sufficiently suitable to the geological factors of drilling. Specifically, there are instances of loss of borehole stability and nonachievement of target output due to low quality of primary reservoir penetration $[14,15]$. In order to improve HCBM application efficiency, it is essential to develop the criteria for assessment of their quality depending on the geological factors of application. Such criteria would provide a possibility of on-the-spot quality control of the drilling mud in the field conditions. Based on multiple years of experience with using HCBM in various petroleum and gas provinces of Russia, we have proposed the following algorithm for quality criteria selection in regard to this type of muds (Fig.).

Figure legend: $V_{\text {d.m }}-$ volume of dispersion medium that separated from emulsion mud after 1 day of settling out, $\mathrm{cm}^{3} ; V_{\mathrm{em}}$ - total volume of emulsion mud, $\mathrm{cm}^{3} ; T_{\mathrm{w} . \mathrm{h}}-$ maximum expected mud temperature at the well head, ${ }^{\circ} \mathrm{C} ; \tau_{0}$-dynamic shear stress, $\mathrm{dPa} ; \eta_{\mathrm{pl}}-$ plastic viscosity, $\mathrm{mPa} \cdot \mathrm{s}$; $\sigma_{\text {st }}$ and $\sigma_{\text {st }}^{\prime}$ - rock sample uniaxial compression strength before and after exposure to the mud, respectively, $\mathrm{MPa} ; \operatorname{tg} \varphi$ and $\operatorname{tg} \varphi^{\prime}-$ internal friction angle tangent in the rock sample before and after exposure to the mud, respectively; $\eta_{\text {eff }}^{\text {res. }}-$ mud effective viscosity at shear rate $5 \mathrm{~s}^{-1}$ at reservoir temperature and surface temperature, respectively, $\mathrm{mPa} \cdot \mathrm{s}$.

\section{HCBM stability indicators}

Regardless of geological factors of drilling, HCBM should possess high aggregative and kinetic stability characterized by the following indicators: electrical stability, daily settling-out, and sedimentation stability. The daily settling-out value $(\mathrm{SO}, \%)$ reflects $\mathrm{HCBM}$ ability to retain its hydrocarbon phase when in steady state for a prolonged period of time, and should not exceed $5 \%$ (only insignificant settling out of oil is acceptable).

HCBM sedimentation stability indicator $\left(S_{0}, \mathrm{~g} / \mathrm{cm}^{3}\right)$ according to [16] should be maximum $0.02 \mathrm{~g} / \mathrm{cm}^{3}$ for unweighted muds and maximum $0.06 \mathrm{~g} / \mathrm{cm}^{3}$ - for muds with density $1.50 \mathrm{~g} / \mathrm{cm}^{3}$ and 


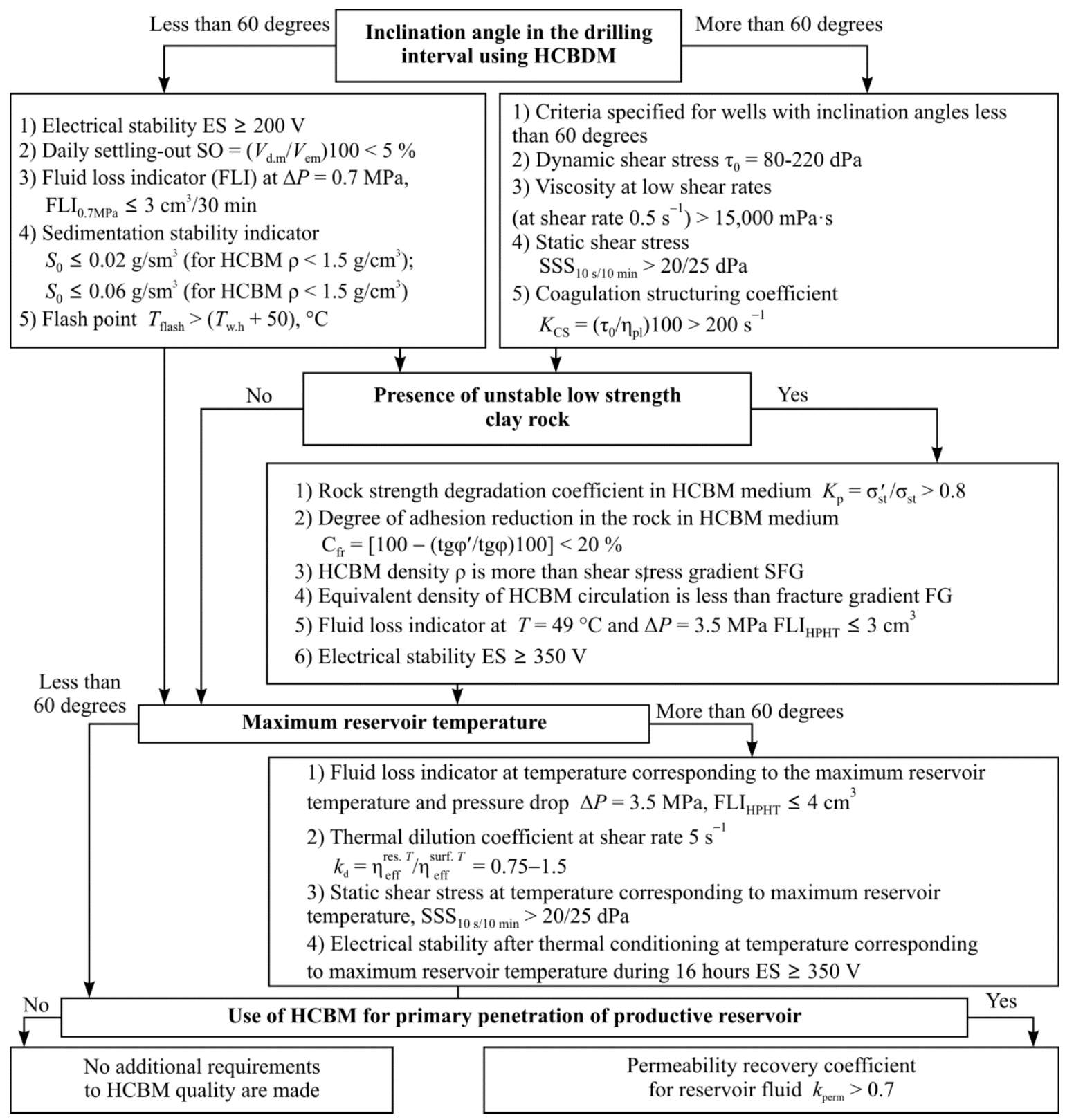

Fig. HCBM quality criteria

more. In foreign drilling practice, the most widely used method for measuring the ability of mud (including HCBM) to retain weighting material is the so-called Sag Factor, $S F$, which is defined using the formula:

$$
S F=\left(\frac{M W_{\text {bottom }}}{M W_{\text {bottom }}+M W_{\text {top }}}\right),
$$

where $M W_{\text {bottom }}$ and $M W_{\text {top }}$ are mud densities on the bottom and at the top of the cylinder.

At $S F \leq 0.50$ it is considered that the mud is capable of retaining the weighting material, whereas higher $S F$ values mean that in operation the mud can cause problems due to generation of sludge and barite "pads" in the well bore [17].

As we mentioned above, the main requirement to HCBM recipe is high stability of emulsion system. Stability of invert emulsion muds depends on the characteristics of emulsion process and degree of water phase dispersion. The emulsion process which occurs at the stage of HCBM preparation can be viewed as two-phase. During phase 1 the mechanical impact results in occurrence of both "oil in water" and "water in oil" emulsions. During phase 2, one of the emulsion types is stabilized by the emulsifier which is present in the system [8, 18]. The main parameter that characterizes aggregative stability of 
HCBM to coalescence of disperse phase globules is the electrical stability (ES) indicator. The essence of its measurement is as follows. The external medium for HCBM is nonpolar fluid (oil) which does not conduct electricity. When the device probe with two parallel plate electrodes is immersed in the mud and electrical voltage is applied, emulsion breakdown (inversion) occurs. Current conducting water medium becomes external medium in the emulsion volume confined between the device electrodes, and starts conducting electrical current. The more is the voltage required for emulsion inversion, the higher is the HCBM aggregative stability. The electrical stability indicator correlates with strength of interphase adsorption layers around the water phase globules and with the distance between them. Based on the results of laboratory studies, apart from the aggregate stability (ability of the water phase to coalesce), HCBM electrical stability indicator value depends on a number of additional factors unrelated to the emulsion stability. Specifically, the electrical stability indicator value decreases:

- with increase of water phase concentration (due to reduced distances between the water globules);

- with increase of water phase mineralization value (due to increase of its specific electrical conductivity);

- with increase of the value of hydrophiliclyophilic balance of the emulsifiers used in the system (due to increase of their polar properties);

- with increase of weighting materials solid phase concentration in the system (due to the presence of residual water particles on their surface).

Based on the analysis of the above-mentioned factors, we believe that it is fair to use this parameter, in the first place, for estimation in regard to each specific HCBM recipe. ISO 104142:2011 [19] also mentions that evaluation of hydrophobic condition of the drilling mud solely on the basis of electrical stability is unreasonable. When the decision concerning drilling mud conditioning has to be based on ES values, only dynamics of this indicator over time should be taken into account.

Specialists of foreign service companies recommend to assume $350 \mathrm{~V}$ as the minimum ES value (according to OFITE, FANN testers). Based on many years of practical HCBM handling experience during the USSR times, V.I. Tokunov and B.I. Heifets established that at electrical stability levels exceeding $150 \mathrm{~V}$ (according to IGER-1 meter), the mud is stable, does not manifest proneness to phase inversion or require additional conditioning with stabilizers [18]. Below this value, phase inversion is possible if production conditions change (HCBM contamination with reservoir water, cement, drilling sludge etc).

Based on the laboratory research results and experience of HCBM application, it can be established that in order to prevent phase inversion of the emulsion, HCBM electrical stability value should be at least $200 \mathrm{~V}$ accounting for possible negative impacts of contaminants (drilling sludge and reservoir water) on the system, since even at electrical stability values within 100-200 V, the mud remains stable and as a filtrate contains hydrocarbon fluid without signs of water phase (Table 1). When penetrating hydrophilic terrigenous collectors, in our opinion, it is reasonable to maintain electrical stability at the level of at least $350 \mathrm{~V}$ to minimize osmotic processes in the "drilling mud - rock" system.

Table 1

Dependence between HCBM fluid loss properties and emulsifiers concentration

\begin{tabular}{|c|c|c|c|c|c|}
\hline \multirow[b]{2}{*}{ Emulsifier concentration and type } & \multirow[b]{2}{*}{ ES, V } & \multirow{2}{*}{$\mathrm{FLI}_{\mathrm{HPHT}}, \mathrm{cm}^{3} / 30 \mathrm{~min}$} & \multicolumn{3}{|c|}{ Filtrate content, $\%$} \\
\hline & & & oil & emulsion & water \\
\hline $1 \%$ Emultal & 120 & 6.4 & 25 & 75 & 0 \\
\hline $2 \%$ Emultal & 350 & 6.0 & 17 & 83 & 0 \\
\hline $3 \%$ Emultal & 610 & 6.4 & 16 & 84 & 0 \\
\hline $5 \%$ Emultal & 1000 & 4.8 & 20 & 80 & 0 \\
\hline $1 \%$ Devon $4 \mathrm{~V}$ grade $\mathrm{A}$ & 80 & 4.6 & 48 & 52 & 0 \\
\hline $2 \%$ Devon $4 \mathrm{~V}$ grade $\mathrm{A}$ & 120 & 4.8 & 17 & 83 & 0 \\
\hline $3 \%$ Devon $4 \mathrm{~V}$ grade $\mathrm{A}$ & 304 & 3.8 & 20 & 80 & 0 \\
\hline $5 \%$ Devon $4 \mathrm{~V}$ grade $\mathrm{A}$ & 430 & 3.9 & 10 & 90 & 0 \\
\hline
\end{tabular}

N o t e : fluid loss research has been performed using HCBM based on mineral oil with 50/50 hydrocarbons to water ratio at $T=149{ }^{\circ} \mathrm{C}$ and $\Delta P=500$ psi. Emultal is an emulsifier based on fatty acids ethers; Devon $4 \mathrm{~V}$ grade $\mathrm{A}$ is an emulsifier based on fatty acids amides. 
One of the well-known defects of this type of muds is their high cost [20]. Based on the previous conclusion concerning the recommended ES value, we believe that use of HCBM in uncomplicated conditions, and in the role of process fluids for elimination of sticking and improvement of hydrophobic properties of unstable intervals, use of recipes with high concentration of expensive components (primary and secondary emulsifiers and gelling agents) is unjustified, as it results in unreasonable significant increase in chemicals cost.

\section{HCBM quality criteria in case of drilling extended reach wells}

In case of drilling convoluted well paths (with inclination angles exceeding 60 degrees), additional requirements exist in regard to HCBM rheological and structural-cum-mechanical properties that characterize its carry-up ability (in regard to drilling sludge) and retaining ability (in regard to weighting materials). According to the experience of HCBM application in Volga-Ural and Timan-Pechora petroleum and gas provinces, HCBM dynamic shear stress indicator should be within 80-220 dPa, viscosity indicator at low shear rates measured with Brookfield viscometer - at least $15,000 \mathrm{mPa} \cdot \mathrm{s}$ (at shear rate $\approx 0.5 \mathrm{~s}^{-1}$ ), static shear stress indicator - at least 20/25 dPa.

In case of penetration of unstable terrigenous deposits, especially clay rock belonging to "weak" category in terms of contact strength (contact strength less than $300 \mathrm{kgf} / \mathrm{cm}^{2}$, compression strength less than $30 \mathrm{MPa}$ [21]), with inclination angles exceeding 60 degrees, in order to reduce the probability of complications related to wellbore instability, the priority criteria of HCBM quality are their inhibiting properties.

Most researchers a priori believe that all nonwater-based process liquids, including HCBM, containing water phases of various compositions, are similar in terms of their inhibiting properties in regard to unstable rocks and clay minerals of the collector [22]. At the same time, osmotic processes are not taken into account. We believe that by purposely changing the composition of HCBM water phase and its fluid loss indicator value, it is possible to slow down the process of interaction between clay and mud and thus increase the "stable state" time of the wellbore walls in the clay rock interval. However, only scientifically justified approach to HCBM recipe selection using drill samples of problematic intervals will help prevent hydration and preserve (conserve) the initial structural and mechanical strength of clays at the wellbore wall.

We propose to evaluate HCBM inhibiting properties in regard to highly lithified clay rock (argillites, clay slate) based on the following indicators:

- rock strength degradation coefficient (water resistance coefficient) $K_{\mathrm{p}}=\sigma_{\mathrm{st}}^{\prime} / \sigma_{\mathrm{st}}$, where $\sigma_{\mathrm{st}}$ and $\sigma_{\text {st }}^{\prime}-$ rock sample uniaxial compression strength before and after exposure to mud, respectively;

- Degree of adhesion reduction in the rock matrix characterized by the value of internal friction angle tangent $\operatorname{tg} \varphi: \mathrm{C}_{\mathrm{fr}}=\left[100-\left(\operatorname{tg} \varphi^{\prime} / \operatorname{tg} \varphi\right) 100\right], \%$, where $\operatorname{tg} \varphi$ and $\operatorname{tg} \varphi^{\prime}-$ internal friction angle tangent in the rock sample before and after exposure to mud, respectively.

Table 2

Dynamics of rock strength properties in HCBM medium

\begin{tabular}{|c|c|c|c|c|}
\hline \multirow[b]{2}{*}{ Drilling mud type } & \multicolumn{2}{|c|}{$K_{\text {sd }}$} & \multicolumn{2}{|c|}{$\mathrm{D}_{\mathrm{adh}}, \%$} \\
\hline & $\begin{array}{c}\text { after } 7 \text { days of contact } \\
\text { with HCBM } \\
\end{array}$ & $\begin{array}{c}\text { after } 14 \text { days of } \\
\text { contact with HCBM }\end{array}$ & $\begin{array}{c}\text { after } 7 \text { days of contact } \\
\text { with HCBM }\end{array}$ & $\begin{array}{c}\text { after } 14 \text { days of } \\
\text { contact with HCBM }\end{array}$ \\
\hline $\begin{array}{l}\text { HCBM based on service water } \\
(\mathrm{HC} / \mathrm{W}-50 / 50)\end{array}$ & 0.45 & 0.40 & 34.0 & 40.0 \\
\hline $\begin{array}{l}\text { HCBM based on saturated potassium } \\
\text { chloride solution }(\mathrm{HC} / \mathrm{W}-50 / 50)\end{array}$ & 0.49 & 0.45 & 32.0 & 38.9 \\
\hline $\begin{array}{l}\text { HCBM based on saturated calcium } \\
\text { chloride solution }(\mathrm{HC} / \mathrm{W}-50 / 50)\end{array}$ & 1.0 & 1.0 & 0 & 0 \\
\hline $\begin{array}{l}\text { HCBM based on saturated calcium } \\
\text { chloride solution }(\mathrm{HC} / \mathrm{W}-90 / 10)\end{array}$ & 1.0 & 1.0 & 0 & 0 \\
\hline Anhydrous HCBM (thickened oil) & 1.0 & 1.0 & 0 & 0 \\
\hline
\end{tabular}

$\mathrm{N}$ o t e : HC/W - percentage ratio between hydrocarbon and water in HCBM recipe. 
As an example, Table 2 shows the results of research concerning dynamics of strength properties in the rock of Timanian terrigenous horizon at one of the Perm Krai fields (average over several parallel determinations) after exposure to HCBM medium with different water phase compositions.

According to [23], rock is considered to be high-strength if its softening coefficient equal to the ratio between its compression strength after contact with water medium and its initial strength, amounts to at least 0.8 . Similarly to the abovementioned indicator, we believe that the strength degradation coefficient in HCBM medium for clay rock in problematic drilling intervals should not be less than 0.8. Based on the results of previous research it has been established that $K_{\mathrm{d}}=0.8$ correlates with $\mathrm{C}_{\mathrm{fr}}=20 \%$.

In a number of petroleum and gat regions, there is certain terrigenous rock that, in contact with the water phase, adsorbs water almost instantly and cracks along the stratification planes. Such rock can be classified as "geomechanically weak" and is characterized by low strength [24]. The example of such rock is Timanian-Sargayev (Kynovian) horizon deposits belonging to the Devonian system, Vanden suite rock [25].

The rock under consideration is mostly represented by argillites and clay slates, and as a rule has a well-developed system of micro-cracks with subparallel orientation. The problem of loss of stability in such rock is caused by cumulative action of the two factors. The first factor is related to the loss of rock stability due to release of the current tectonic stress in the course of the rock mass penetration by the well, and is physical in its nature. The second factor (the effect of microcracks propping in the rock under the pressure of drilling mud filtrate) is physicochemical [26-29]. Only through elimination of these two factors it is possible to ensure fault-free drilling conditions in wells with horizontal tailing-in at the sites where caprock consists of unstable low strength clay rock $[25,30-32]$.

When drilling through low strength rock, in order to compensate for the variation of tangential and radial stress in the well bore, HCBM density should exceed the shear stress gradient calculated through construction of a geomechanical wellbore stability model. Equivalent density of HCBM circulation calculated on the basis of mud rheological indicators in order to exclude cracking resulting from excessive hydrodynamic pressures should be below fracture gradient.

\section{HCBM quality criteria in complicated thermobaric drilling conditions}

In the conditions of the wells with high reservoir temperatures, HCBM should possess, apart from the above-mentioned properties, sufficient thermal stability and stability of the required (operating) indicators of fluid loss, rheological and structural-cum-mechanical properties in a wide range of temperatures - from $T=20{ }^{\circ} \mathrm{C}$ (average mud temperature in surface process reservoirs) to the maximum reservoir temperature (as per the design data). More than 2fold change of HCBM viscosity at low shear rates in downhole conditions vs. mud viscosity on the surface results in significant deterioration in quality of horizontal wellbore cleaning, sludge and weighting material deposition, friction factor growth, tool obstruction and dragging, sticking (including differential) [33, 34]. And vice versa, significant increase in HCBM viscosity due to mud temperature reduction (which is common for surface volume of mud after lengthy circulation interruptions) results in thickening to the extent of no-flow condition, which makes the mud difficult to pump.

We assume reservoir temperature of $T=60{ }^{\circ} \mathrm{C}$ as critical, since in the instance of construction of wells with lower reservoir temperatures, the drilling experience suggests that mud circulation temperature does not exceed $49{ }^{\circ} \mathrm{C}$ (temperature for measurement of the basic HCBM rheological indicators according to GOST 33697-2015 [35]).

We suggest using thermal dilution coefficient at shear rate $5 \mathrm{~s}^{-1}\left(k_{\mathrm{d}}\right)$ as HCBM thermal stability criterion for wells with reservoir temperatures exceeding $60^{\circ} \mathrm{C}$, based on the following formula:

$$
k_{\mathrm{d}}=\eta_{\mathrm{eff}}^{\text {res. } T} / \eta_{\mathrm{eff}}^{\text {surf. } T},
$$

where $\eta_{\text {eff }}^{\text {res. }}-$ HCBM effective viscosity at shear rate $5 \mathrm{~s}^{-1}$ at reservoir temperature; $\eta_{\text {eff }}^{\text {surf } T}-\mathrm{HCBM}$ effective viscosity at shear rate $5 \mathrm{~s}^{-1}$ at mud surface temperature.

Effective viscosity value at low shear rates (at shear rate $5 \mathrm{~s}^{-1}$ or less) characterizes HCBM suspension capacity in the wall-adjacent area, including downhole conditions [36]. The specified 
HCBM thermal dilution coefficients depending on the gelling agent type used in the system

\begin{tabular}{|l|c|c|c|c|c|c|c|c|c|c|}
\hline \multirow{2}{*}{ Basic system gelling agent } & \multicolumn{9}{c|}{$k_{\mathrm{d}}$ at measurement temperature, ${ }^{\circ} \mathrm{C}$} & \multirow{2}{*}{$S_{0}$ at } \\
\cline { 2 - 11 } & 25 & 30 & 40 & 50 & 60 & 70 & 80 & 90 & $T=90{ }^{\circ} \mathrm{C}$ \\
\hline Polyisobutylene $(\mathrm{Mr}=4,000-6,000)$ & 1 & 0.86 & 0.8 & 0.76 & 0.74 & 0.73 & 0.72 & 0.72 & 0.08 \\
\hline Polyisobutylene $(\mathrm{Mr}=15,000-25,000)$ & 1 & 0.93 & 0.87 & 0.84 & 0.82 & 0.8 & 0.78 & 0.76 & 0.04 \\
\hline Modified butadiene-styrene latex & 1 & 1.1 & 1.18 & 1.25 & 1.31 & 1.36 & 1.36 & 1.36 & 0 \\
\hline Organobentonite & 1 & 0.85 & 0.8 & 0.74 & 0.73 & 0.71 & 0.7 & 0.7 & 0.1 \\
\hline
\end{tabular}

N o t e s : $S_{0}$ - Sedimentation stability indicator, $\mathrm{g} / \mathrm{cm}^{3}$; HCBM content, vol. \%: diesel fuel -53.5 ; calcium chloride solution - 33.5 ; emulsifier $-3 \%$; gelling agent (concentration selected empirically to receive static shear stress values at the level of $30 \mathrm{dPa}$ ); barite -10 .

shear rate value is also selected because $5 \mathrm{~s}^{-1}$ $(3 \mathrm{rpm})$ is the lowest rate at which it is possible to measure effective viscosity by rotary viscometers (OFITE, FANN) that are most widely applied in the field mud analysis practice. The fact that HCBM effective viscosity increases with the growth of temperature in the specified shear rate range signifies improvement of mud suspension capacity with increase of temperature, which is especially important when drilling convoluted well paths. Use of the thermal dilution coefficient calculated with the suggested formula helps eliminate the need for complicated equipment and enables real-time HCBM quality control based on thermal stability indicator in field conditions using standard equipment. As an example, Table 3 shows the calculated values of HCBM thermal dilution coefficient depending on the type of the gelling agent used in the system. The table shows that reduction of the system viscosity at $T=90{ }^{\circ} \mathrm{C}$ by more than 1.5 times is related to the loss of the system's sedimentation stability.

Based on the laboratory research results, it has been established that the impact of excessive pressure on HCBM rheological properties is insignificant; specifically, pressure increase from atmospheric to $1.4 \mathrm{MPa}$ increases the values of the basic HCBM rheological properties by $10-20 \%$. Therefore, we believe that introduction of an indicator that would describe HCBM quality preservation depending on system baric conditions change is impractical.

Another HCBM quality criterion related to ensuring drilling operations safety, with increasing importance in conditions of wells with high reservoir temperatures, is mud flash point temperature $\left(T_{\text {flash }}\right)$. Specifically, p. 220 of the "Safety rules in oil and gas industry" [37] stipulates the requirement to HCBM flash point temperature, which should exceed the maximum expected mud temperature at the well mouth $\left(T_{\mathrm{w} . \mathrm{h}}\right)$ by $50{ }^{\circ} \mathrm{C} . \quad T_{\text {w.h }}$ is calculated using standard formulas [38].

\section{Quality criteria for reservoir drilling}

Presently HCBM have proven efficiency for primary penetration of productive reservoirs in the conditions where real well output with the use of drilling mud water systems for reservoir penetration is much lower than potentially possible [6, 39]. This is especially relevant for hydrophobic collectors as well as collectors where cementing substance is represented by hydrophilic clay materials. So, application of HCBM at Van Yogan field helped resume drilling of horizontal wells by reducing the number of complications and start development of other areas in previously unprofitable reserves (productivity index for wells drilled using waterbased mud amounted to an average of $0.4 \mathrm{~m}^{3} /$ day/atm, HCBM $-1.45 \mathrm{~m}^{3} /$ day/atm) [40]. However, there are instances of target output underachievement due to unsuitability of HCBM recipes to geological factors of drilling and geological settings of the productive reservoir [41]. When using HCBM for primary penetration of the productive reservoir, the priority quality criterion should be the permeability recovery coefficient. It is also recommended to evaluate permeability variation in the composite formation model (CFM) by reservoir fluid (oil) at the specific field. Thus it is possible to take into account the physicochemical processes that occur in the "reservoir oil - drilling mud filtrate - core" 
system. Based on the experience of core samples testing in regard to different types of drilling muds, the permeability recovery coefficient by reservoir fluid $\left(K_{\text {recov. CFM }}\right)$ for high quality penetration of the productive reservoir is calculated by the formula:

$$
K_{\text {recov. CFM }}=\frac{K_{\text {perm.2 CFM }}}{K_{\text {perm.1 CFM }}},
$$

where $K_{\text {perm. } 2 \text { CFM }}$ - CFM permeability by reservoir oil after filtration of the drilling mud under research; $K_{\text {perm. } 1 \text { CFM }}$ - initial CFM permeability by reservoir oil.

For HCBM this coefficient should not exceed 0.7 .

Notably, the research aiming at evaluation of $K_{\text {recov. CFM should be performed at reservoir }}$ temperature and static and dynamic repression values calculated based on reservoir pressures and drilling mud static and equivalent circulation density.

\section{Conclusion}

The range of possible applications of hydrocarbon-based drilling muds in the state-ofthe-art well construction technology is defined by a number of additional specific requirements to indicators of their process properties. The study proposes HCBM quality assessment criteria that help improve application efficiency of this type of drilling muds, especially for construction of wells in complicated geological conditions. On-the-spot control of most of the indicators used as HCBM quality criteria can be performed during operation in field conditions. Some of the indicators, specifically rock strength degradation coefficient and permeability recovery coefficient, cannot be controlled in field conditions. Only prior research in laboratory conditions can substantiate approval (rejection) of technology suitable for application at a given well. This is especially relevant for mud recipes intended for well trial operation.

\section{References}

1. Korshak A.A., Shammazov A.M. Osnovy neftegazovogo dela [Basics of oil and gas business]. Ufa, Dizayn poligraf servis, 2001, $544 \mathrm{p}$.

2. Popov A.N., Spivak A.I., Akbulatov T.O. et al. Tekhnologiya bureniya neftyanykh i gazovykh skvazhin [Technology of drilling oil and gas wells]. Ed. A.I. Spivak. Moscow, Nedra-Biznestsentr, 2003, 509 p.

3. Oganov A.S. et al. Otechestvennyy i zarubezhnyy opyt bureniya naklonno-napravlennykh i gorizontalnykh skvazhin $\mathrm{s}$ bolshim otkloneniem stvola ot vertikali [Domestic and foreign experience in drilling directional and horizontal wells with a large deviation of the borehole from the vertical]. Neftegazovye tekhnologii, 2000, no.2, pp.16-20.

4. Arslanbekov A., Sevodin N., Valuev D. et al. Application and optimization of oil-based drilling fluids for ERD wells YNAO area. Paper SPE 136310 presented at the SPE Russian Oil and Gas Conference and Exhibition. Moscow, 26-28 October, 2010. DOI: 10.2118/136310-MS

5. Khvoshchin P., Lyadova N., Iliasov S. et al. The results of horizontal well drilling using invert-emulsion fluid at Kharyaginskoe Field. Paper SPE 171283 presented at the SPE Russian Oil and Gas Exploration \& Production Technical Conference and Exhibition. Moscow, 14-16 October, 2014. DOI: 10.2118/171283-MS

6. Glushchenko V.N., Orlov G.A., Silin M.A. Tekhnologicheskie protsessy vskrytiya plastov i dobychi nefti s ispolzovaniem obratnykh emulsiy [Technological processes of reservoir penetration and oil production using inverse emulsions]. Moscow, Interkontakt nauka, 2008, 360 p.

7. Frazer L.J. How to select drilling fluid for horizontal wells. Word Oil, 1993, vol.214, pp.59-63.
8. Emulsions: fundamentals and applications in the petroleum industry. Ed. L.L. Schramm. Washington, ACS, 1992, $428 \mathrm{p}$

9. Praktikum po kolloidnoy khimii (kolloidnaya khimiya lateksov i po-verkhnostno-aktivnykh veshchestv) [Work book on colloid chemistry (colloid chemistry of latex and surfactant)]. Ed R.E. Neyman. Moscow, Vysshaya shkola, 1971, $176 \mathrm{p}$.

10. Melekhin A.S. Opyt stroitelstva gorizontalnykh skvazhin na Kyrtaelskom mestorozhdenii OOO "LUKOYLKOMI". Borba s oslozhneniyami pri burenii [Experience in the construction of horizontal wells at the Kyrtaelskoye field of LUKOIL-KOMI LLC. Fighting with drilling complications]. Inzhenernaya praktika, 2012, no.2, pp.72-75.

11. Fefelov Yu.V., Karasev D.V., Natsepinskaya A.M., Nekrasova I.L. Burovye rastvory na nevodnoy osnove dlya bureniya skvazhin s bolshim pri-lozheniem [Non-water based drilling fluids for drilling wells with large deviation]. Geologiya, geofizika i razrabotka neftyanykh $i$ gazovykh mestorozhdeniy, 2007, no.9, pp.47-48.

12. Shevchuk V.V. et al. Gidrofobnyy emulsionnyy burovoy rastvor [Hydrophobic emulsion drilling mud]. A.S. 1020428 CCCP, C 09K 7/06. No.3322836/23-03 (1983).

13. Aston M., Mihalik P., Tunbridge J. Towards zero fluid loss oil based muds. Paper SPE 77446 presented at the SPE Annual Technical Conference and Exhibition. San Antonio, Texas, 29 September - 2 October, 2002. DOI: 10.2118/77446-MS

14. Mukhin L.K. Burovye rastvory na uglevodorodnoy osnove dlya bureniya $\mathrm{v}$ oslozhnennykh usloviyakh i vskrytiya produktivnykh plastov: dissertatsiya na soiskanie uchenoy stepeni doktora tekhnicheskikh nauk [Hydrocarbon-based 
drilling fluids for drilling in complicated conditions and the opening of productive layers: dissertation for the degree of Doctor of Engineering]. Moscow, MINKh i GP, 1971, 148 p.

15. Novikov V.S. Ustoychivost glinistykh porod pri burenii skvazhin [Stability of clay rocks during drilling]. Moscow, Nedra, 2000, 270 p.

16. Ryazanov Ya.A. Entsiklopediya po burovym rastvoram [Encyclopedia on muds]. Orenburg, Letopis, 2005, 664 p.

17. Omland T.H., Saasen A., Amundsen P.A. Detection techniques determining weighting material sag in drilling fluid and relationship to rheology. Annual transactions of the Nordic rheology society, 2007, vol. 15.

18. Tokunov V.I., Kheyfets I.B. Gidrofobnoemulsionnye burovye rastvory [Hydrophobic emulsion drilling mud]. Moscow, Nedra, 1983, 167 p.

19. ISO 10414-2:2011 Petroleum and natural gas industries - Field testing of drilling fluids. Part 2: Oilbased fluids, $157 \mathrm{p}$.

20. Christiansen C. From oil-based mud to water-based mud. Paper SPE-23359-MS presented at the SPE Health, Safety and Environment in Oil and Gas Exploration and Production Conference, 11-14 November, The Hague, Netherlands 1991. DOI: 10.2118/23359-MS

21. Epifantsev O.G., Pletenchuk N.S. Otsenka prochnosti gornykh porod po mineralnomu sostavu [Evaluation of rock strength by mineral composition]. Metodicheskie ukazaniya po vypolneniyu laboratornoy raboty dlya studentov gornykh $i$ stroitelnykh spetsialnostey. Novokuznetsk, Izdatelskiy tsentr SibGIU, 16 p.

22. Simpson J.P. Studies dispel myths, give guidance on formulation of drilling fluids for shale stability. IADC/Paper SPE 39376 presented at the 1998 IADC/SPE Drilling Conference held in Dallas, Texas, 3-6 March 1998. DOI: 10.2118/39376-MS

23. Mikulskiy V.G. et al. Stroitelnye materialy (materialovedenie, stroitelnye materialy) [Construction materials (materials science, building materials)]. Moscow, Izdatelstvo Assotsiatsii stroitelnykh vuzov, 2004, 536 p.

24. Nekrasova I.L., Garshina O.V., Khvoshchin P.A. Teoriya i praktika is-polzovaniya invertno-emulsionnykh rastvorov $\mathrm{v}$ protsesse stroitelstva skvazhin [Theory and practice of using invert-emulsion solutions in the process of well construction]. Perm, Aster, 2016, 148 p.

25. Okromelidze G.V. et al. razrabotka kompleksnoy tekhnologii bezavariynoy provodki skvazhin $\mathrm{s}$ gorizontalnym okonchaniem na otlozheniya devonskoy sistemy (na primere Andreevskogo mestorozhdeniya) [Development of complex technology for accident-free drilling of wells with horizontal end section in deposits of the Devonian system (on the example of the Andreevskoye field)]. Otchet o NIR. Perm, Filial OOO "LUKOYLInzhiniring" "PermNIPIneft" v g. Permi, 2015, 137 p.

26. Cheng-Fa L. A new technique for evaluation of shale stability in the presence of polymeric drilling fluid. SPE production Engineering, 1988, vol.3, no.3, pp.366-374. DOI: 10.2118/14249-PA

27. Norov A.D., Gaydarov A.M., Khubbatov A.A. Vybor burovykh rastvorov dlya stabilizatsii stenok skvazhin [Selection of drilling fluids to stabilize well walls]. Gazovaya promyshlennost, 2015, no.3, pp.85-88.

28. Garshina O.V., Predein A.A., Klykov P.I., Khvoshchin P.A., Nekrasova I.L. Geomekhanicheskoe modelirovanie kak neotemlemaya chast kompleksnogo podkhoda $\mathrm{k}$ stroitelstvu skvazhin v slozhnykh gorno-geologicheskikh usl [Geomechanical modeling as an integral part of a complex approach to wells construction in complicated geological conditions]. Oilfield engineering, 2017, no.5, pp.28-33.

29. Bol G.M., Davidson C.J., Woodland D.C. Borehole stability in shales. SPE Drilling\&Completion, 1994, vol.9, iss.02, pp.87-94. DOI: 10.2118/24975-PA

30. Kiselev P., Dobrokhleb P., Dementyev A. Application and optimization of drill-in fluids for achimov horizontal wells in west Siberia. Paper SPE 187697-MS presented at the SPE Russian Petroleum Technology Conference, Moscow, 16-18 October 2017. DOI: 10.2118/187697-MS

31. Aadnoy B.S., Chenevert M.E. Stability of highly inclined boreholes. SPE Drilling Engineering, SPE Drilling Engineering, 1987, vol.2, iss.04, pp.364-374.

32. Bradley W.B. Mathematical concept stress cloud can predict borehole failure. The Oil and Gas Journal, 1979, Feb. 19, pp.92-102.

33. Amani M. The rheological properties of oil-based mud under high pressure and high temperature conditions. Advances in Petroleum Exploration and Development, 2012, vol.3, no.2, pp.21-30. DOI: 10.3968/j.aped.1925543820120302.359

34. Herzhaft B., Rousseau L., Neau L. et al. Influence of temperature and clays/emulsion microstructure on oil-based mud low shear rate rheology. Paper SPE 86197 presented at SPE Annual Technical Conference and Exhibition. San Antonio, Texas, 29 September - 2 October, 2002. DOI: 10.2118/77818-MS

35. GOST 33697-2015. Rastvory burovye na uglevodorodnoy osnove. Kontrol parametrov v promyslovykh usloviyakh [Hydrocarbon based muds. Parameter control in field conditions]. Moscow, Standartinform, 2016, 122 p.

36. Solovev A.Ya. Sovershenstvovanie kachestva burovykh emulsionnykh rastvorov primeneniem reagentov kompleksnogo deystviya [Improving the quality of drilling emulsion solutions using complex reagents]. Ph. D. Thesis. Ufa, 2003, 234 p.

37. Pravila bezopasnosti $v$ neftyanoy $i$ gazovoy promyshlennosti federalnye normy i pravila $\mathrm{v}$ oblasti promyshlennoy bezopasnosti [Safety rules in the oil and gas industry Federal rules and regulations in the field of industrial safety]. Seriya 08, iss.19. Moscow, Nauchnotekhnicheskiy tsentr issledovaniy problem promyshlennoy bezopasnosti, 2013, $288 \mathrm{p}$.

38. Solovev E.M. Zadachnik po zakanchivaniyu skvazhin [Practice book on well completion]. Moscow, Nedra, 1989, $251 \mathrm{p}$.

39. Mnatsakanov A.V. et al. Primenenie invertnoemulsionnykh burovykh rastvorov pri provodke glubokikh skvazhin $\mathrm{v}$ Belorussii [The use of invert-emulsion drilling mud when drilling deep wells in Belarus]. OI. Seriya "Burenie". Moscow, VNIIOENG, 1978, 45 p.

40. Arslanbekov A.R. et al. Vskrytie gidrofobnykh kollektorov $\mathrm{S}$ is-polzovaniem burovykh rastvorov na uglevodorodnoy osnove [Drilling of hydrophobic reservoirs using hydrocarbon-based muds]. Burenie i neft, 2014, no.9, pp.29-32. 
41. Ilyasov S.E. et al. Issledovanie vliyaniya razlichnykh sistem burovykh rastvorov na pervichnoe vskrytie kollektorov Toboyskogo mestorozhdeniya (etapy 2,3 i 4): otchet o NIR [Investigation of the influence of various drilling fluid systems on the drilling of reservoirs of the Toboyskoye field (stages 2, 3 and 4): scientific and research report]. Perm, Filial OOO "LUKOYLInzhiniring" "PermNIPIneft" v g. Permi, 2016, 99 p.

\section{Библиографический список}

1. Коршак А.А., Шаммазов А.М. Основы нефтегазового дела: учеб. для вузов. - Уфа: Дизайн Полиграф Сервис, 2001. - 544 с.

2. Технология бурения нефтяных и газовых скважин: учеб. для вузов / А.Н. Попов, А.И. Спивак, Т.О. Акбулатов [и др.]; под общей ред. А.И. Спивака. - М.: Недра-Бизнесцентр, 2003. - 509 с.

3. Отечественный и зарубежный опыт бурения наклонно-направленных и горизонтальных скважин с большим отклонением ствола от вертикали / А.С. Оганов [и др.] // Нефтегазовые технологии. 2000. - № 2. - C. 16-20.

4. Application and optimization of oil-based drilling fluids for ERD wells YNAO area / A. Arslanbekov, N. Sevodin, D. Valuev [et al.] // Paper SPE 136310 presented at the SPE Russian Oil and Gas Conference and Exhibition. - Moscow, Russia, 26-28 October, 2010. DOI: $10.2118 / 136310-\mathrm{MS}$

5. The results of horizontal well drilling using invertemulsion fluid at Kharyaginskoe Field / P. Khvoshchin, N. Lyadova, S. Iliasov[et al.] // Paper SPE 171283 presented at the SPE Russian Oil and Gas Exploration \& Production Technical Conference and Exhibition, 14-16 October, 2014. - Moscow, 2014. DOI: 10.2118/171283-MS

6. Глущенко В.Н., Орлов Г.А., Силин М.А. Технологические процессы вскрытия пластов и добычи нефти с использованием обратных эмульсий. М.: Интерконтакт Наука, 2008. - 360 с.

7. Frazer L.J. How to select drilling fluid for horizontal wells // Word Oil. - 1993. - Vol. 214. - P. 59-63.

8. Emulsions: fundamentals and applications in the petroleum industry / Ed. by L.L. Schramm. - Washington: ACS, 1992. $-428 \mathrm{p}$.

9. Практикум по коллоидной химии (коллоидная химия латексов и поверхностно-активных веществ): учеб. пособие для вузов / под ред. Р.Э. Неймана. М.: Высшая школа, 1971. - 176 с.

10. Мелехин А.С. Опыт строительства горизонтальных скважин на Кыртаельском месторождении ООО «ЛУКОЙЛ-КОМИ». Борьба с осложнениями при бурении // Инженерная практика. - 2012. - № 2. - С. 72-75.

11. Буровые растворы на неводной основе для бурения скважин с большим приложением / Ю.В. Фефелов, Д.В. Карасев, А.М. Нацепинская, И.Л. Некрасова // Геология, геофизика и разработка нефтяных и газовых месторождений. - 2007. - № 9. - С. 47-48.

12. А.С. 1020428 СССР, С 09К 7/06. Гидрофобный эмульсионный буровой раствор / Шевчук В.В. [и др.]; заявитель и патентообладатель Ин-т общей и неорган. химии АН БССР №3322836/23-03; заявл. 17.07.1981; опубл. 30.05.1983, Бюл. № 20.

13. Aston M., Mihalik P., Tunbridge J. Towards zero fluid loss oil based muds // Paper SPE 77446 presented at the SPE Annual Technical Conference and Exhibition, 29 September - 2 October. - San Antonio, 2002. DOI: $10.2118 / 77446-\mathrm{MS}$

14. Мухин Л.К. Буровые растворы на углеводородной основе для бурения в осложненных условиях и вскрытия продуктивных пластов: дис. ... д-ра техн. наук. - М.: МИНХ и ГП, 1971. - 148 с.

15. Новиков В.С. Устойчивость глинистых пород при бурении скважин: учеб. пособие. - М.: Недра, 2000. $-270 \mathrm{c}$.

16. Рязанов Я.А. Энциклопедия по буровым растворам. - Оренбург: Летопись, 2005. - 664 с.

17. Omland T.H., Saasen A., Amundsen P.A. Detection techniques determining weighting material sag in drilling fluid and relationship to rheology // Annual transactions of the Nordic rheology society. - 2007. - Vol. 15.

18. Токунов В.И., Хейфец И.Б. Гидрофобноэмульсионные буровые растворы. - М.: Недра, 1983. - $167 \mathrm{c}$.

19. ISO 10414-2:2011. Petroleum and natural gas industries - Field testing of drilling fluids. Part 2: Oilbased fluids. $-157 \mathrm{p}$.

20. Christiansen C. From oil-based mud to waterbased mud // Paper SPE-23359-MS presented at the SPE Health, Safety and Environment in Oil and Gas Exploration and Production Conference, 11-14 November, The Hague, Netherlands, 1991. DOI: 10.2118/23359-MS

21. Епифанцев О.Г., Плетенчук Н.С. Оценка прочности горных пород по минеральному составу: метод. указания по выполнению лабораторной работы для студентов горных и строительных специальностей. Новокузнецк: Издательский центр СибГИУ. - 16 с.

22. Simpson J.P. Studies dispel myths, give guidance on formulation of drilling fluids for shale stability. IADC/Paper SPE 39376 presented at the 1998 IADC/SPE Drilling Conference held in Dallas, Texas, 3-6 March 1998. DOI: $10.2118 / 39376-\mathrm{MS}$

23. Строительные материалы (материаловедение, строительные материалы) / В.Г. Микульский [и др.]. М.: Изд-во Ассоциации строительных вузов, 2004. - 536 с.

24. Некрасова И.Л., Гаршина О.В., Хвощин П.А. Теория и практика использования инвертно-эмульсионных растворов в процессе строительства скважин: моногр. - Пермь: Астер, 2016. - 148 с.

25. Разработка комплексной технологии безаварийной проводки скважин с горизонтальным окончанием на отложения девонской системы (на примере Андреевского месторождения) : отчет о НИР / Г.В. Окромелидзе [и др.] / филиал ООО «ЛУКОЙЛИнжиниринг» «ПермНИПИнефть» в г. Перми. Пермь, 2015. - 137 с.

26. Cheng-Fa L. A new technique for evaluation of shale stability in the presence of polymeric drilling fluid // 
SPE production Engineering. - 1988. - Vol. 3, № 3. P. 366-374. DOI: $10.2118 / 14249-P A$

27. Норов А.Д., Гайдаров А.М., Хуббатов А.А. Выбор буровых растворов для стабилизации стенок скважин // Газовая промышленность. - 2015. - № 3. - С. 85-88.

28. Геомеханическое моделирование как неотъемлемая часть комплексного подхода к строительству скважин в сложных горно-геологических условиях / O.В. Гаршина, А.А. Предеин, П.И. Клыков, П.А. Хвощин, И.Л. Некрасова // Нефтепромысловое дело. - 2017. - № 5. - С. 28-33.

29. Bol G.M., Davidson C.J., Woodland D.C. Borehole stability in shales // SPE Drilling\&Completion. - 1994. Vol. 9, iss. 02. - P. 87-94. DOI: 10.2118/24975-PA

30. Kiselev P., Dobrokhleb P., Dementyev A. Application and optimization of drill-In fluids for achimov horizontal wells in West Siberia // Paper SPE 187697-MS presented at the SPE Russian Petroleum Technology Conference, Moscow, Russia, 16-18 October 2017. DOI: $10.2118 / 187697-M S$

31. Aadnoy B.S., Chenevert M.E. Stability of highly inclined boreholes // SPE Drilling Engineering, 1987 SPE Drilling Engineering. - Vol. 2, iss. 04. - P. 364-374.

32. Bradley W.B. Mathematical concept stress cloud can predict borehole failure // The Oil and Gas Journal. 1979. - Feb. 19. - P. 92-102.

33. Amani M. The rheological properties of oil-based mud under high pressure and high temperature conditions // Advances in Petroleum Exploration and Development. - 2012. - Vol. 3, no. 2. - P. 21-30. DOI: $10.3968 /$ j.aped.1925543820120302.359

34. Influence of temperature and clays/emulsion microstructure on oil-based mud low shear rate rheology /
B. Herzhaft, L. Rousseau, L. Neau [et al.] // Paper SPE 86197 presented at SPE Annual Technical Conference and Exhibition. - San Antonio, Texas, 29 September 2 October, 2002. DOI: 10.2118/77818-MS

35. ГОСТ 33697-2015. Растворы буровые на углеводородной основе. Контроль параметров в промысловых условиях. - М.: Стандартинформ, 2016. -122 c.

36. Соловьев А.Я. Совершенствование качества буровых эмульсионных растворов применением реагентов комплексного действия: дис. ... канд. техн. наук. - Уфа, 2003. - 234 с.

37. Правила безопасности в нефтяной и газовой промышленности Федеральные нормы и правила в области промышленной безопасности. Серия 08, вып. 19. М.: Научно-технический центр исследований проблем промышленной безопасности, 2013. - 288 с.

38. Соловьев Е.М. Задачник по заканчиванию скважин. - М.: Недра, 1989. - 251 с.

39. Применение инвертно-эмульсионных буровых растворов при проводке глубоких скважин в Белоруссии / А.В. Мнацаканов [и др.] // ОИ. Сер «Бурение». - М.: ВНИИОЭНГ, 1978. - 45 с.

40. Вскрытие гидрофобных коллекторов с использованием буровых растворов на углеводородной основе / А.Р. Арсланбеков [и др.]// Бурение и нефть. - 2014. - № 9. - С. 29-32.

41. Исследование влияния различных систем буровых растворов на первичное вскрытие коллекторов Тобойского месторождения (этапы 2, 3 и 4): отчет о НИР / С.Е. Ильясов [и др.] / Филиал ООО «ЛУКОЙЛ-Инжиниринг» «ПермНИПИнефть» в г. Перми. - Пермь, 2016. - 99 с.

Please cite this article in English as:

Nekrasova I.L. Improvement of the criteria for assessing the quality of hydrocarbon-based muds in terms of geological conditions of their use. Perm Journal of Petroleum and Mining Engineering, 2018, vol.18, no.2, pp.129-139. DOI: 10.15593/2224-9923/2018.4.3

Просьба ссылаться на эту статью в русскоязычных источниках следующим образом:

Некрасова И.Л. Совершенствование критериев оценки качества буровых растворов на углеводородной основе в зависимости от горно-геологических условий их применения // Вестник Пермского национального исследовательского политехнического университета. Геология. Нефтегазовое и горное дело. - 2018. - Т.18, №2. - C.129-139. DOI: 10.15593/2224-9923/2018.4.3 